\title{
The finding of Crocidura suaveolens in Saint Petersburg
}

\author{
Irina M. Gorbunova \& Kirill A. Tretyakov
}

\begin{abstract}
Lesser white-toothed shrews were trapped in Saint Petersburg in 2000-2009. It is the most northern finding for this species.

KEY WORDS: Crocidura suaveolens, northern population.

Irina M. Gorbunova [irishg@yandex.ru]. Antiplague station of Saint-Petersburg, Nevelskaya st. 3., Saint Petersburg, 198035, Russia; Kirill A. Tretyakov [k-sanych@yandex.ru] Zoological Institute, Russian Academy of Sciences, Universitetskaya nab. 1., Saint Petersburg, 199034, Russia.
\end{abstract}

\section{Находка of Crocidura suaveolens в Санкт-Петербурге}

\section{И.М. Горбунова, К.А. Третьяков}

РЕЗЮМЕ. В период с 2000 по 2009 г. на территории Санкт-Петербурга были пойманы несколько экземпляров малых белозубок. Это самая северная находка для вида.

КЛЮЧЕВЫЕ СЛОВА: Crocidura suaveolens, северная популяция.

Most species of Crocidura Wagler, 1832 can be found in southern areas of the northern hemisphere in Europe and Siberia (Sokolov, 1973). As reported by Pavlinov et al. (2002), five species of the genus Crocidura live in the Russian federation. Such species as $C$. gueldenstaedti Pallas, 1811, C. lasiura Dobson, 1890, C. leucodon Hermann, 1780, and C. sibirica Dukelsky, 1930 can be found in the southern part of Russia only. As pointed out by Gureev (1979), C. suaveolens was not observed north of Moscow Province while the southern limit of its distribution range belongs to Kazakhstan and Altai. However, recently lesser white-toothed shrews were reported at higher latitudes such as Moscow (Karaseva et al., 1999) and the region of Ural (Bolshakov et al., 2005).

C. suaveolens as a species is not listed in the book "Mammals of Leningrad province" (Novikov et al., 1970). On the contrary, there are historical evidences that, a century ago, lesser white-toothed shrews lived in Karelia and Estonia (Siivonen, 1979). One animal (male) of this species was trapped in 1986 in Gatchina District (Leningrad Region) near a cattle-breeding farm (Svimonishvili, 1992). Respectively, some exemplars of $C$. suaveolens have been reported from buildings located in the region of Ural (Chernousova \& Tolkachev, 2006). The findings mentioned above clearly speak in favor of the synanthropic status of that species (Gureev, 1979; Pavlinov et al., 2002).

Continuous observations of lesser white-toothed shrews in the harbor area of St. Petersburg during nine years (2000-2009) came as a surprise. Small mammals belonging to 7 species (246 specimens in total) (Tab. 1) were trapped in different places during 1670 trapping events. Two female were trapped in September 2002 and a male and a female in January 2007.

Lesser white-toothed shrews were trapped only in a building belonging to a former warehouse (Tab. 1) and were not observed at all outside of that building. In other northern areas these mammals were seen in gardens and forest-parks (Karaseva et al., 1999; Chernousova \& Tolkachev, 2006). We believe that $C$. suaveolens can not survive outside of buildings in our region. We can conclude that Crocidura spp. can not tolerate low temperatures, contrary to Sorex spp. Therefore, lesser white-toothed shrews can not be expected to be found outside of houses and commercial buildings at the latitude of St. Petersburg. On the other hand, Crocidura spp. show a well-developed ecological adaptability. Thus, C. suaveolens can eat grain food, which is not the case with Sorex spp. It is highly probable that St. Petersburg is constitutes the most northern region were C. suaveolens presently live.

Table 1. Number of mammals in captured different habitats on the territory of the St. Petersburg harbor.

\begin{tabular}{|l|c|c|c|c|c|c|c|}
\hline Habitat & $\begin{array}{c}\text { Sorex } \\
\text { araneus }\end{array}$ & $\begin{array}{c}\text { Crocidura } \\
\text { suaveolens }\end{array}$ & $\begin{array}{c}\text { Mus } \\
\text { musculus }\end{array}$ & $\begin{array}{c}\text { Rattus } \\
\text { norvegicus }\end{array}$ & $\begin{array}{c}\text { Microtus } \\
\text { arvalis }\end{array}$ & $\begin{array}{c}\text { Apodemus } \\
\text { agrarius }\end{array}$ & $\begin{array}{c}\text { Rattus } \\
\text { rattus }\end{array}$ \\
\hline former warehouse & 1 & 4 & 74 & 110 & & & 1 \\
\hline open habitats & & & & 46 & 3 & 7 & \\
\hline
\end{tabular}


What was the path that white-toothed shrews took to St. Petersburg? C. suaveolens may have arrived in St. Petersburg with food commercially transported from the southern regions. Presence of lesser white-toothed shrews in the former warehouse makes a good evidence of that. The consistency of findings of $C$. suaveolens during recent years speaks in favor of the stability of its population.

\section{References}

Bolshakov V.N., Chernousova N.F.\& Galchina I.I. 2005. [Lesser white-toothed shrews (Crocidura suaveolens) finding in Ural] // Zoologicheskii Zhurnal. Vol.84. No.5. P.646-638 [in Russian, with English summary].

Chernousova N.F. \& Tolkachev O.V. 2006. [New population of Crocidura suaveolens (Pallas, 1811) in Ural] //
Izvestiya Chelyabinskogo Universiteta. Vol.33. No.3. P.94-100 [in Russian].

Gureev A.A. 1979. [Fauna of the USSR]. Leningrad: Nauka. 502 p. [In Russian]

Karaseva E.V., Telicina A.U. \& Samoilov B.L. 1999. [Mammals of Moscow]. Moskva: Nauka. 245 p. [in Russian]

Novikov G.A., Airapet'yants A.E., Pukinskii Yu.B., Strelkov P.P., Timofeeva E.K. 1970. [Mammals of Leningrad Province]. Leningrad: Nauka. 360 pp. [in Russian]

Pavlinov I.Ya., Kruskop S.V., Varshavskii A.A. \& Borisenko A.V. 2002. [Terrestrial mammals of Russia]. Moskva: Izdatel'stvo Moskovskogo Universiteta. 299 p. [In Russian]

Siivonen L. 1979. [Mammals of Northern Europe]. Moskva: Nauka. 231 pp. [in Russian]

Svimonishvili V.N. 1992. [New data about distribution of lesser white-toothed shrews] // Sokolov V.E. (ed.). [First All-Union Conference on Biology of Insectivorous Mammals]. Moskva: VASKHNIL. P.155-156 [in Russian]. 